\title{
Prognostic significance of SOX18 expression in non-small cell lung cancer
}

\author{
ALEKSANDRA JETHON $^{1,2}$, BARTOSZ PULA $^{1,2}$, MATEUSZ OLBROMSKI $^{1,2}$, \\ BOZENA WERYNSKA ${ }^{3}$, BEATA MUSZCZYNSKA-BERNHARD ${ }^{4}$, WOJCIECH WITKIEWICZ ${ }^{1}$, \\ PIOTR DZIEGIEL $^{1,2,5}$ and MARZENA PODHORSKA-OKOLOW ${ }^{1,2}$ \\ ${ }^{1}$ Regional Specialist Hospital, Research and Development Centre, 51-124 Wroclaw; \\ ${ }^{2}$ Department of Histology and Embryology, Medical University, 50-368 Wroclaw; ${ }^{3}$ Department of Pulmonology \\ and Pulmonary Tumours, Medical University, 53-439 Wroclaw; ${ }^{4}$ Laboratory of Histopathology, \\ Lower Silesian Centre for Pulmonary Diseases, 53-439 Wroclaw; ${ }^{5}$ Department of Physiotherapy, \\ Wrocław University School of Physical Education, 51-612 Wroclaw, Poland
}

Received July 31, 2014; Accepted September 9, 2014

DOI: $10.3892 /$ ijo.2014.2698

\begin{abstract}
Recent studies have demonstrated the involvement of SOX18 transcription factor in blood and lymphatic vessel development, as well as in wound healing processes. SOX18 expression has been noted in cancer cells of various tumours, including lung cancer. However, the exact role of SOX18 expression in non-small cell lung cancer (NSCLC) remains to be determined. The present study, therefore, assessed its expression in 198 cases of NSCLC, consisting of 94 adenocarcinomas (AC), 89 squamous cell carcinomas (SQC) and 15 large cell carcinomas (LCC). The analysis utilized immunohistochemistry (IHC) and, in 42 cases, molecular methods. SOX18 expression was also determined in NSCLC cell lines (NCI-H1703, NCI-H522 and A549) and in normal lung fibroblasts (IMR-90). SOX18 was found to be expressed in nuclei, as well as in the cytoplasm of cancer cells, in the majority of studied cases. SOX18 mRNA expression was significantly lower in NSCLC than in non-malignant lung tissue $(\mathrm{P}<0.0001)$. However, SOX18 protein expression levels were higher in NSCLC tissues $(\mathrm{P}<0.005)$ and in the examined lung cancer cell lines. No SOX18 expression was noted in the IMR-90 cell line. In paraffin sections, a positive correlation between the Ki-67 antigen and nuclear SOX18 expression $(r=0.17, \mathrm{P}<0.05)$ was noted. In univariate survival analysis, cytoplasmic SOX18 expression correlated with poor patient outcome in the whole study and in AC cohorts (both $\mathrm{P}<0.05$ ). Based on these results, SOX18 may be involved in the progression of NSCLC.
\end{abstract}

Correspondence to: Professor Marzena Podhorska-Okolow, Department of Histology and Embryology, Wrocław Medical University, Chałubińskiego 6a, 50-368 Wroclaw, Poland

E-mail: marzenna.podhorska-okolow@umed.wroc.pl

Key words: non-small cell lung cancer, SOX18, Ki-67 antigen, prognosis

\section{Introduction}

Lung cancer is the most common malignancy worldwide (accounting for $\sim 12 \%$ of cancers) in terms of both incidence and mortality. In addition, a tendency toward increased incidence is estimated (1). More than $80 \%$ of diagnosed lung cancers belong to the group of non-small cell carcinomas (NSCLC), and the majority of these cases are diagnosed in advanced disease stages (2). In view of these facts, the discovery of new prognostic and predictive factors is of high importance.

The SOX (sex-determining region on the Y chromosomerelated high mobility group box) genes encode a group of transcription factors sharing a high-mobility group (HMG) domain, which specifically binds to the 5 '-(A/T)(A/T)CAA (A/T)G-3' DNA sequence motif $(3,4)$. Through binding with DNA, whether directly or indirectly via co-factors, SOX proteins are capable of regulating transcription. Unlike most transcription factors, the members of the SOX family modify the conformation of DNA by binding to its minor groove (5). Moreover, they are capable of sequestering other transcription factors into complexes (5). The SOX family is divided into ten groups (A-J) based on their amino acid homology (5). SOX18, along with SOX7 and SOX17, is part of the F group (SOX F) of SOX proteins $(3,5)$. Accumulating lines of evidence suggest that SOX18 may influence neonatal, as well as postnatal, vascularization (6-10). Furthermore, SOX7 and SOX17 have been shown to possess some homology, and may complement the function of SOX18 during the above-mentioned procesess $(8,11)$. It has been shown that mutations in SOX18 can lead to defective blood and lymphatic vessel formation, what is observed in the hypotrichosis-lymphedema-telangiectasia syndrome (12-14).

Recent findings indicate that SOX18 may play an important role in tumour growth (15-17). SOX18 expression has been found in cancer cell lines of various malignancies, including breast, gastric and pancreatic cancers (18). Recently, we found that SOX18 expression increases in invasive ductal breast cancer (IDC) cells, and that its expression increases with malignancy 
grade and amplification of human epidermal growth factor receptor 2 (HER2) (19). In addition, Eom et al (20) found that SOX18, along with SOX7 and SOX17, was overexpressed in gastric cancer tissues, compared to corresponding normal tissues. Analysis of SOX18 immunostained slides showed that SOX18 expression was exclusively noted in the stromal cells (but not in the cancer cells) of the analysed gastric cancers, and its high expression correlated with poor patient survival (20). Evidence suggests that SOX18 expression may also be involved in cell proliferation. Inhibition of SOX18 expression in MCF-7 breast cancer cells and in vascular smooth muscle cells of human atherosclerotic lesions has been observed to lead to decreased proliferation rates in both cell lines $(16,21)$.

To date, SOX18 expression in lung cancer cell lines and tissues has only been studied on the mRNA level. It has been shown that its expression is lower in NSCLC tissues and cancer cell lines; this is associated with increased $\mathrm{CpG}$ island hypermethylation of $S O X 18$ promoter $(22,23)$. Moreover, the prognostic significance of SOX18 expression in NSCLC has not yet been determined. In the present study, we therefore, analysed SOX18 expression on the mRNA and on the protein level in a cohort of NSCLC cases, putting emphasis on the clinical and pathological data of the patients in order to determine its prognostic significance.

\section{Materials and methods}

Patients and clinical samples. The present study was approved by the Bioethics Commission at the Wroclaw Medical University and investigations were performed after a written informed consent was obtained. The studies were performed on archival material originating from 198 samples of NSCLC taken during surgical resections in 2007-2012 at the Lower Silesia Centre for Pulmonary Diseases in Wroclaw. The study group consisted of 94 adenocarcinomas (AC), 89 squamous cell carcinomas (SQC) and 15 large cell carcinomas (LCC). All the samples used in the present study were collected prior to administration of chemotherapy and radiotherapy. The pTNM classification was made according to the recommendations of the International Association for the Study of Lung Cancer (IASLC) (24). Clinical data were derived from hospital archives and are summarized in Table I. The mean observation time of patients was $27.49 \pm 37.19$ months (range, 1-147). During this time, 100 (50.5\%) of the patients died.

In each case, the paraffin sections were stained with hematoxylin/eosin (H\&E) and assessed by two independent pathologists to verify the utility of the samples for immunohistochemical (IHC) studies, the diagnosis, and the degree of tumour malignancy. In case of 42 NSCLC patients, resected tumour fragments and additional non-malignant lung tissue (NMLT) adjacent to the primary tumour of the same 29 patients were collected into RNAlater RNA stabilizing fluid (Qiagen, Hilden, Germany) and stored at $-20^{\circ} \mathrm{C}$ until realtime PCR studies were performed. The group consisted of 23 AC, 16 SQC and 3 LCC cases (Table I). NSCLC and NMLT tissues were also collected and frozen in liquid nitrogen and stored at $-80^{\circ} \mathrm{C}$ in the case of eight patients.

Cell lines. Three NSCLC cell lines (NCI-H1703, NCI-H522 and A549) and a normal lung fibroblast cell line (IMR-90) obtained from the American Type Culture Collection (ATCC, Manassas, VA, USA) were used in the present study. The NCI-H1703 cell line was derived from stage I SQC, the NCI-H522 cell line from stage II AC and the A549 cell line from a highly malignant $\mathrm{AC}$.

Both NCI-H1703 and NCI-H522 cell lines were cultured in RPMI-1640 medium with the addition of $2 \mathrm{mM}$ L-glutamine (Lonza, Basel, Switzerland). The A549 cell line was grown in high glucose DMEM medium and $2 \mathrm{mM}$ L-glutamine, whereas the fibroblastic IMR-90 cell line in the MEM medium was supplemented with non-essential amino acids (Sigma, St. Louis, MO, USA). All media were also supplemented with fetal bovine serum (Sigma), up to a final concentration of $10 \%$. These cell lines were cultured at $37^{\circ} \mathrm{C}$ and at $5 \% \mathrm{CO}_{2}$.

Immunhistochemistry. IHC reactions were performed using a previously established protocol in Autostainer Link 48 (DakoCytomation, Glostrup, Denmark) to ensure repeatable experimental conditions. Murine monoclonal antibodies directed against SOX18 (Santa Cruz Biotechnology, Santa Cruz, CA, USA) and Ki-67 (clone MIB-1; DakoCytomation) were utilized.

The sections were first boiled in Target Retrieval Solution buffer ( $\mathrm{pH} 9.0$ for SOX18 and $\mathrm{pH} 6.0$ for Ki-67) using a Pre-Treatment link platform (in order to deparaffinize, rehydrate, and unmask the antigens) and subsequently cooled in a rinsing buffer (TBS/ $0.1 \%$ Tween). The activity of endogenous peroxidase was blocked by $5 \mathrm{~min}$ incubation with EnVision FLEX peroxidase-blocking reagent. EnVision FLEX System was used to visualize the antigens. After rinsing the slides in TBS $/ 0.1 \%$ Tween buffer, the primary antibodies were applied for $20 \mathrm{~min}$ at room temperature. Next, the slides were again rinsed in buffer and incubated for 20 min with secondary antibodies, EnVision FLEX/HRP. To visualize the reaction, sections were incubated for $10 \mathrm{~min}$ with EnVision FLEX working solution, where 3,3'-diaminobenzidine (DAB) was used as a chromogen. All slides were counterstained with EnVision FLEX hematoxylin. Subsequently, the sections were dehydrated in alcohol and xylene, and then mounted in SUB-X mounting medium. All the equipment and reagents besides the SOX18 antibody were obtained in DakoCytomation.

Evaluation of IHC reactions. All IHC sections were evaluated using a BX41 light microscope (Olympus, Tokyo, Japan) by two independent pathologists who were blinded to the patients' clinical data. SOX18 expression was analysed depending on the cellular localization in the NSCLC cancer cells. Cytoplasmic SOX18 (cSOX18) expression was assessed using the immunoreactive score (IRS) of Remmele and Stegner (25). This scale evaluates the percentage of cells with positive reaction ( 0 points, absence of cells with positive reaction; 1 point, $1-10 \%$ cells with positive reaction; 2 points, $11-50 \% ; 3$ points, $51-80 \%$; 4 points, over $80 \%$ cells with positive reaction) and the intensity of the reaction $(0$, no reaction; 1 , low intensity of the reaction product; 2 , moderate intensity of the reaction colour; and 3, intense colour of the reaction). In the case of nuclear SOX18 (nSOX18) and Ki-67 expression in NSCLC cancer cells, a semi-quantitative scale based on tumour cell positivity in the whole tissue section was employed (26). 
Table I. Clinical and pathological data of the studied patients with non-small cell lung cancer.

\begin{tabular}{|c|c|c|c|c|c|}
\hline Parameters & $\begin{array}{c}\text { All cases } \\
(\mathrm{N}=198) \\
\mathrm{n}(\%)\end{array}$ & $\begin{array}{c}\mathrm{AC} \\
(\mathrm{N}=94) \\
\mathrm{n}(\%)\end{array}$ & $\begin{array}{c}\text { SQC } \\
(\mathrm{N}=89) \\
\mathrm{n}(\%)\end{array}$ & $\begin{array}{c}\text { LCC } \\
(\mathrm{N}=15) \\
\mathrm{n}(\%)\end{array}$ & $\begin{array}{l}\text { Real-time PCR } \\
\qquad \begin{array}{c}(\mathrm{N}=42) \\
\mathrm{n}(\%)\end{array}\end{array}$ \\
\hline \multicolumn{6}{|l|}{ Age (years) } \\
\hline Mean & $63.45 \pm 8.6$ & $62.4 \pm 9.15$ & $63.13 \pm 7.21$ & $64.61 \pm 8.14$ & $65.17 \pm 8.37$ \\
\hline Range & $(39-82)$ & $(39-80)$ & $(54-77)$ & $(41-82)$ & $(51-82)$ \\
\hline \multicolumn{6}{|l|}{ Gender } \\
\hline Male & $149(75.3)$ & $70(74.5)$ & $69(77.5)$ & $10(66.7)$ & $32(76.2)$ \\
\hline Female & $49(24.7)$ & $24(25.5)$ & $20(22.5)$ & $5(33.3)$ & $10(23.8)$ \\
\hline \multicolumn{6}{|l|}{ Tumour size } \\
\hline pT1 & $59(29.8)$ & $27(28.7)$ & $26(29.2)$ & $6(40)$ & $15(35.7)$ \\
\hline pT2 & $97(49.0)$ & $44(46.8)$ & $46(51.7)$ & $7(46.6)$ & $21(50)$ \\
\hline pT3 & $19(9.6)$ & $7(7.5)$ & $11(12.4)$ & $1(6.7)$ & 5 (11.9) \\
\hline pT4 & $23(11.6)$ & $16(17)$ & $6(6.7)$ & $1(6.7)$ & $1(2.4)$ \\
\hline \multicolumn{6}{|c|}{ Lymph nodes } \\
\hline $\mathrm{pNO}$ & $97(49.0)$ & $35(37.2)$ & $52(58.4)$ & $10(66.7)$ & $25(59.5)$ \\
\hline $\mathrm{pN} 1, \mathrm{pN} 2$ & $101(51.0)$ & $59(62.8)$ & $37(41.6)$ & $5(33.3)$ & $17(40.5)$ \\
\hline \multicolumn{6}{|l|}{ Stage } \\
\hline IA & $45(22.7)$ & $19(20.2)$ & $21(23.5)$ & $5(33.3)$ & $11(26.2)$ \\
\hline IB & $36(18.2)$ & $13(13.8)$ & $20(22.5)$ & $3(20)$ & 7 (16.7) \\
\hline IIA & $23(11.6)$ & $11(11.8)$ & $11(12.4)$ & $1(6.7)$ & $8(19)$ \\
\hline IIB & $17(8.6)$ & $5(5.4)$ & $11(12.4)$ & $1(6.7)$ & $5(11.9)$ \\
\hline IIIA & $53(26.7)$ & $29(30.7)$ & $20(22.5)$ & $4(26.6)$ & $9(21.4)$ \\
\hline IIIB & $14(7.1)$ & $9(9.6)$ & $4(4.5)$ & $1(6.7)$ & - \\
\hline IV & $10(5.1)$ & $8(8.5)$ & $2(2.2)$ & - & $2(4.8)$ \\
\hline \multicolumn{6}{|c|}{ Malignancy grade } \\
\hline G1 & $9(5.0)$ & $5(5.3)$ & $4(4.5)$ & - & $3(7.1)$ \\
\hline $\mathrm{G} 2$ & $136(74.3)$ & $68(72.4)$ & $68(76.4)$ & - & $27(64.3)$ \\
\hline G3 & 38 (20.7) & $21(22.3)$ & $17(19.1)$ & - & $12(28.6)$ \\
\hline
\end{tabular}

AC, adenocarcinoma; SQC, squamous cell carcinoma; LCC, large cell carcinoma. Age is expressed in years, all other data are expressed as $\mathrm{n}(\%)$.

This scale is encoded as: 0 ( $0 \%$ cells stained), 1 (1-10\% cells stained), 2 (11-25\% cells stained), 3 (26-50\% cells stained) and 4 (51-100\% cells stained).

RNA extraction and cDNA synthesis, real-time PCR. The total RNA from the analysed cell lines (NCI-H1703, NCI-H522, A549 and IMR-90), NSCLC, and NMLT tissues was isolated using the RNeasy Mini kit (both Qiagen), according to the manufacturer's instructions. The protocol included on-column DNAse digestion to eliminate the genomic DNA. RNA quality and integrity were determined by an Agilent 2100 Bioanalyzer on RNA Pico Chips (both Agilent Technologies, Santa Clara, CA, USA). First-strand cDNA was synthesized using the QuantiTect Reverse Transcription kit (Qiagen).

The relative levels of SOX18 mRNA expression were determined by quantitative real-time PCR using the 7900HT Fast Real-Time PCR System and a TaqMan Gene Expression Master Mix (Applied Biosystems, Foster City, CA, USA), according to the manufacturer's protocols, as in a previous study (19). The primers used were SOX18 Hs00746079_s1 for SOX18 and SDHA Hs00188166_m1 for SDHA (Applied Biosystems), the latter serving as a reference for determining SOX18 expression levels (27). The reactions were carried out in triplicate under the following conditions: initial denaturation at $94^{\circ} \mathrm{C}$ for $120 \mathrm{sec}$, followed by 40 cycles of denaturation at $94^{\circ} \mathrm{C}$ for $15 \mathrm{sec}$, and annealing and elongation at $60^{\circ} \mathrm{C}$ for $60 \mathrm{sec}$. The relative mRNA expression levels of SOX18 were calculated using the $\Delta \Delta \mathrm{Ct}$ method.

SDS-PAGE and western blot technique. The present study was performed using previously established experimental protocols (19). Whole protein lysates were obtained from the cell lines under study using a Cell Lytic buffer, and from the sampled NSCLC and NMLT tissues using the T-Per tissue protein extraction reagent with the addition of protease inhibitors (both Sigma). In the case of the cell lines, the cytoplasmic and nuclear fractions were obtained using a ProteoExtract subcellular proteome extraction kit according to the manufacturer's instructions. The samples were then centrifuged again $\left(4^{\circ} \mathrm{C}, 10 \mathrm{~min}, 10,000 \mathrm{x} \mathrm{g}\right)$ to collect the nuclear extracts. 


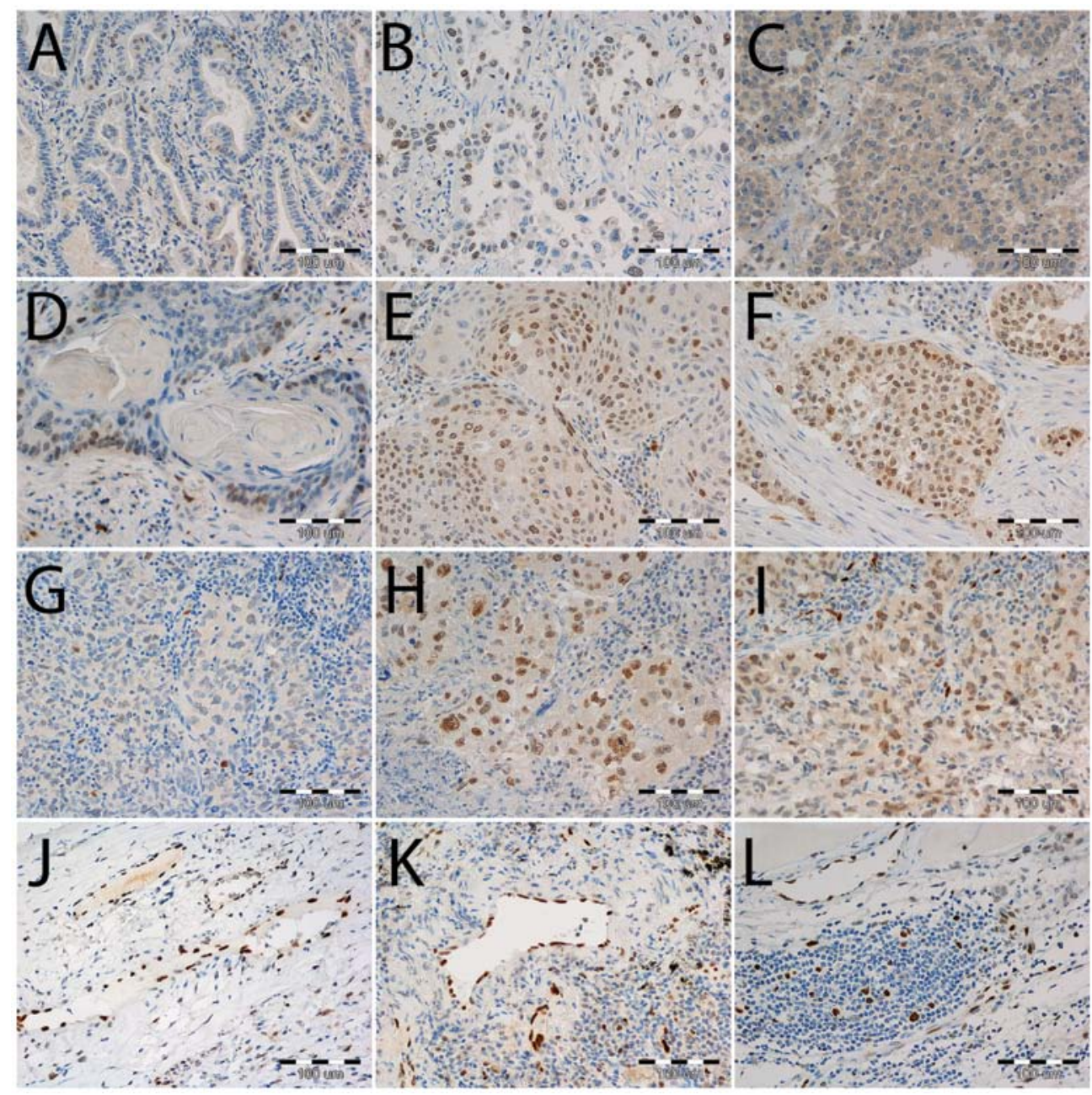

Figure 1. Differentiated SOX18 expression in adenocarcinomas (AC; A-C), squamous cell carcinomas (SQC; D-F), and large cell carcinomas (LCC; G-I). All of the analysed histological types of non-small cell lung carcinomas presented with either weak (A, D and G) or intense nuclear (B, E and H) or cytoplasmic (C, F and I) SOX18 immunoreactivity. It is noteworthy that almost all cases demonstrated mixed expression types in both the described cell compartments (B, $\mathrm{F}$ and H). No SOX18 expression was visible in the fibroblastic-like cells of the tumour stroma. SOX18 expression was noted in nuclei of vessels (J, K and L), and of some of the immune cells in the tumour stroma ( $\mathrm{K}$ and L). Original magnification, $\mathrm{x} 200$.

Whole-cell, nuclear and cytoplasmic proteins were quantified using the BCA protein assay (Pierce, Rockford, IL, USA), and resolved on $10 \%$ SDS-PAGE gels using the Laemmli method. After electrophoresis, the samples were transferred to polyvinylidene fluoride (PVDF) membranes (Immobilon; Millipore, Bedford, MA, USA) and incubated with anti-human SOX18 antibody (diluted 1:100; Santa Cruz Biotechnology) overnight at $4^{\circ} \mathrm{C}$. Next, the membranes were incubated with the secondary anti-mouse antibody conjugated with horseradish peroxidase (Jackson ImmunoResearch, Mill Valley, CA, USA) for $1 \mathrm{~h}$ at room temperature, rinsed, and treated with the Immun-Star HRP chemiluminescent kit (Bio-Rad Laboratories, Hercules, CA, USA). $\beta$-actin, detected with anti-human $\beta$-actin antibody (Abcam, Cambridge, UK), was used as an internal control to normalize the amounts of SOX18 on the same membrane.

Statistical analysis. Prism 5.0 (GraphPad Software, La Jolla, CA, USA) statistical software was used to analyse the results. The non-parametric Mann-Whitney U test (for unpaired observations) and the Wilcoxon signed-rank test (for paired observations) were used to compare groups of data. The associations between clinical and pathological parameters and the expression of the studied IHC markers were analysed using the Fisher's exact test, and correlations by the Spearman's correlation test. Survival times were determined by the Kaplan-Meier method, and the significance of the differences was determined by a log-rank test. For each variable, the hazard ratio (HR) and the $95 \%$ confidence interval $(95 \% \mathrm{CI})$ were estimated. In all the analyses, the results were considered statistically significant when $\mathrm{P}<0.05$.

\section{Results}

Relationship between immunohistochemical SOX18 expression in NSCLC and patients' clinical and pathological data. SOX18 expression was noted in cancer cell nuclei, as well as in cytoplasm, in all of the three histological types of NSCLC (Fig. 1). Nuclear SOX18 expression was noted in 187 out of $198(94.4 \%)$ cases, whereas cSOX18 expression was noted in $93(47 \%)$ of the NSCLC cases. SOX18 expression was also observed in nuclei of vessels, and of some of the immune cells in the tumour stroma (Fig. 1). For the purpose of statistical analyses, and based on the median expression levels of nSOX18 and cSOX18, the analysed cases were divided into the 


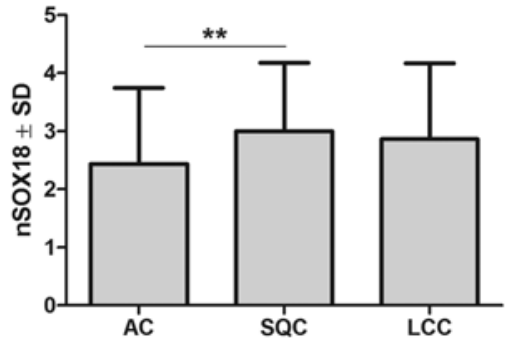

Figure 2. Nuclear SOX18 expression in adenocarcinomas (AC), squamous cell carcinomas (SQC), and large cell carcinomas (LCC). ${ }^{* *} \mathrm{P}<0.005$, MannWhitney U test.
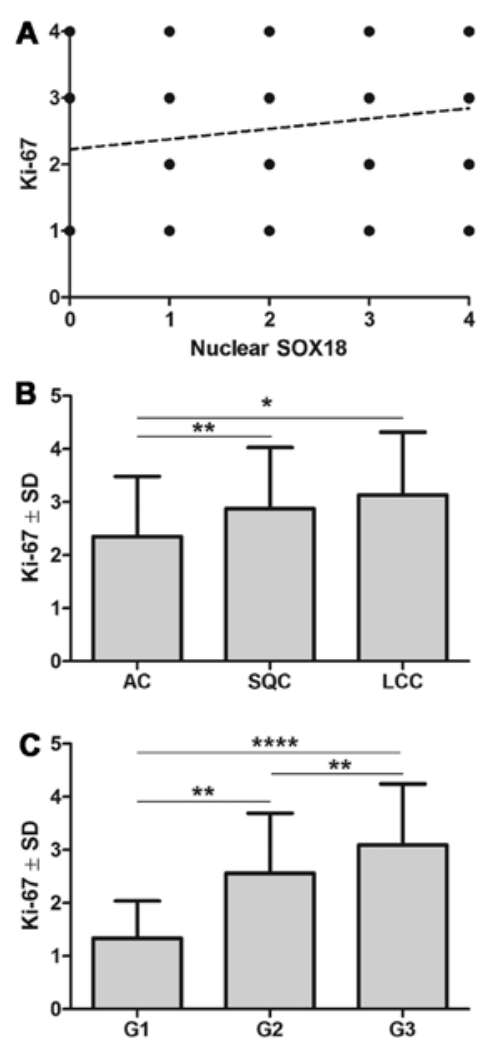

Figure 3. (A) Positive correlation of nuclear SOX18 and Ki-67 antigen ( $r=0.17$, $\mathrm{P}=0.0139$, Spearman correlation test) expression in the whole study cohort. Differential expression of the Ki-67 antigen with regard to histological types (B) of non-small cell lung cancers (AC, adenocarcinomas; SQC, squamous cell carcinomas; LCC, large cell carcinomas) and malignancy grades (G). ${ }^{*} \mathrm{P}<0.05,{ }^{* *} \mathrm{P}<0.005,{ }^{* * *} \mathrm{P}<0.0005,{ }^{* * * * *} \mathrm{P}<0.0001$, Mann-Whitney U test.

following groups: Cases characterized by $\mathrm{nSOX} 18$ expression of $0-2$ points ( $\leq 25 \%$ of positive cells) were regarded as 'low', whereas those scoring 3-4 points ( $>25 \%$ of positive cells) were regarded as 'high'. Similarly, cases presenting no cSOX18 expression were classified as negative, whereas those scoring IRS 1-12 were regarded as positive.

A significant positive correlation was observed between nSOX18 and cSOX18 expression in the whole study cohort $(\mathrm{r}=0.35, \mathrm{P}<0.0001)$, as well as in particular histological types: $\mathrm{AC}(\mathrm{r}=0.30, \mathrm{P}=0.0038), \mathrm{SQC}(\mathrm{r}=0.37, \mathrm{P}=0.0003)$ and $\mathrm{LCC}$ ( $\mathrm{r}=0.56, \mathrm{P}=0.0306$; Spearman correlation test, respectively). Nuclear SOX18 expression was significantly higher in the SQC $(3.00 \pm 2.87)$ than in the $\mathrm{AC}(2.44 \pm 2.87)$ cases $(\mathrm{P}=0.0021$, Mann-Whitney U test; Fig. 2), however, no significant differ-
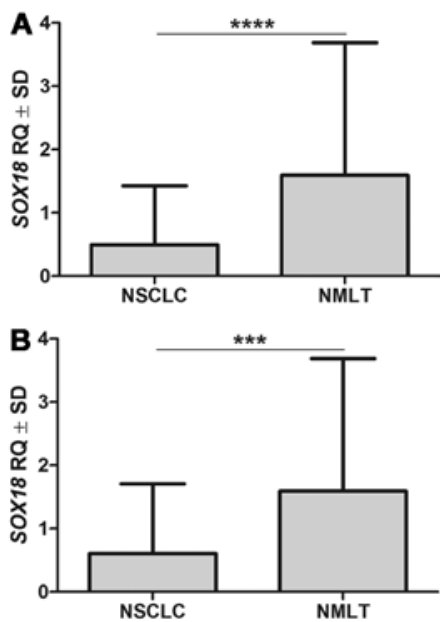

Figure 4. SOX18 mRNA expression determined using real-time PCR in nonmalignant lung tissue (NMLT) and non-small cell lung carcinomas (NSCLC) of all (A; ${ }^{* * * *} \mathrm{P}<0.0001$, Mann-Whitney $\mathrm{U}$ test $)$ and paired $\left(\mathrm{B} ;{ }^{* * *} \mathrm{P}<0.0005\right.$, Wilcoxon signed-rank test) samples.

ences were noted in regard to cSOX18 immunoreactivity between particular NSCLC histological types (AC, IRS

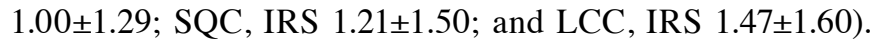
Moreover, nSOX18 expression correlated positively with the expression of the Ki-67 antigen ( $\mathrm{r}=0.17, \mathrm{P}=0.0139$, Spearman correlation test; Fig. 3A). It is noteworthy that Ki-67 antigen expression differed among the particular NSCLC histological types. Significantly lower Ki-67 antigen expression was noted in the AC cases $(2.25 \pm 1.13)$, as compared with the SQC $(2.88 \pm 1.16, \mathrm{P}=0.002)$ and LCC $(3.13 \pm 1.87)$ cases (both MannWhitney U test; Fig. 3B). Ki-67 antigen expression increased with growing malignancy grade of the tumours (G1, 1.33 \pm 0.70 ; G2, 2.56 \pm 1.34 ; and G3, 3.09 \pm 1.15 ). Significant differences were noted using the Mann-Whitney U test between G1 tumours and those of $\mathrm{G} 2$ and $\mathrm{G} 3(\mathrm{P}=0.0024$ and $\mathrm{P}<0.0001$, respectively). Also significant differences were observed between $\mathrm{G} 2$ and G3 cancers ( $\mathrm{P}=0.024$, Mann-Whitney U test; Fig. 3C).

Analysis of nuclear and cytoplasmic SOX18 immunoreactivity in the whole cohort, as well as in the AC and SQC types, revealed that higher nSOX18 expression was associated with male gender of SQC patients $(\mathrm{P}=0.0281$, Fisher's exact test; Table II). However, no other association of nSOX18 and cSOX18 expression levels with the age of the patients, gender, primary tumour size, presence of lymph node metastasis or disease stage were noted (Tables II and III).

SOX18 mRNA and protein expression in NMLT and NSCLC with regard to patients' clinical and pathological characteristics. Real-time PCR analysis of SOX18 mRNA expression was achieved in 39 out of $42(92.9 \%)$ analysed NSCLC samples and in all of the 29 NMLT cases. Significantly higher SOX18 mRNA expression level was observed in NMLT (RQ $1.59 \pm 2.09)$ tissues than in NSCLC, both for all the analysed samples (RQ $0.49 \pm 0.93, \mathrm{P}<0.0001$, Mann-Whitney $\mathrm{U}$ test) and for the paired cases (RQ $0.60 \pm 1.10, \mathrm{P}=0.0004$, Wilcoxon signed-rank test; Fig. 4). In the paired sample analysis, a higher SOX18 mRNA expression was noted in $27(93.1 \%)$ cases of NMLT, as compared with NSCLC. Statistical analysis did not reveal any significant associations between the level of SOX18 
Table II. Association of nuclear SOX18 (nSOX18) expression with the clinical and pathological data of patients.

\begin{tabular}{|c|c|c|c|c|c|c|c|c|c|}
\hline \multirow[b]{2}{*}{ Parameters } & \multicolumn{2}{|c|}{ All cases $(\mathrm{N}=198)$} & \multirow[b]{2}{*}{ P-value } & \multicolumn{2}{|c|}{$\mathrm{AC}(\mathrm{N}=94)$} & \multirow[b]{2}{*}{ P-value } & \multicolumn{2}{|c|}{ SQC (N=89) } & \multirow[b]{2}{*}{ P-value } \\
\hline & $\begin{array}{l}\leq 25 \% \\
\mathrm{n}(\%)\end{array}$ & $\begin{array}{l}>25 \% \\
\mathrm{n}(\%)\end{array}$ & & $\begin{array}{l}\leq 25 \% \\
\mathrm{n}(\%)\end{array}$ & $\begin{array}{l}>25 \% \\
\mathrm{n}(\%)\end{array}$ & & $\begin{array}{l}\leq 25 \% \\
\mathrm{n}(\%)\end{array}$ & $\begin{array}{l}>25 \% \\
\mathrm{n}(\%)\end{array}$ & \\
\hline \multicolumn{10}{|l|}{ Age (years) } \\
\hline$<65$ & $47(40.9)$ & $68(59.1)$ & 0.6599 & $27(46.6)$ & $31(53.4)$ & 1.0000 & $16(34.8)$ & $30(65.2)$ & 0.6592 \\
\hline$\geq 65$ & $31(37.3)$ & $52(62.7)$ & & $16(44.4)$ & $20(55.6)$ & & $13(30.2)$ & $30(69.8)$ & \\
\hline \multicolumn{10}{|l|}{ Gender } \\
\hline Male & $57(38.3)$ & $92(61.7)$ & 0.6147 & $34(48.6)$ & $36(51.4)$ & 0.4769 & $18(26.1)$ & $51(73.9)$ & 0.0281 \\
\hline Female & $21(42.9)$ & $28(57.1)$ & & $9(37.5)$ & $15(62.5)$ & & $11(55)$ & $9(45)$ & \\
\hline \multicolumn{10}{|l|}{ Tumour size } \\
\hline pT1 & $23(39.7)$ & $35(60.3)$ & 1.0000 & $11(40.7)$ & $16(59.3)$ & 0.6487 & $9(34.6)$ & $17(65.4)$ & 0.8077 \\
\hline pT2-pT4 & $55(39.3)$ & $85(60.7)$ & & $32(47.8)$ & $35(52.2)$ & & $20(31.7)$ & $43(68.3)$ & \\
\hline \multicolumn{10}{|c|}{ Lymph nodes } \\
\hline pNO & $39(40.2)$ & $58(59.8)$ & 1.0000 & $19(43.2)$ & $25(56.8)$ & 0.6821 & $18(34.6)$ & $34(65.4)$ & 0.6543 \\
\hline $\mathrm{pN} 1, \mathrm{pN} 2$ & $40(39.2)$ & $62(60.8)$ & & $24(48)$ & $26(52)$ & & $11(29.7)$ & $26(70.3)$ & \\
\hline \multicolumn{10}{|l|}{ Stage } \\
\hline I & $34(43.6)$ & $44(56.4)$ & 0.5569 & $15(46.9)$ & $17(53.1)$ & 1.0000 & $15(36.6)$ & $26(63.4)$ & 0.5018 \\
\hline II-IV & $47(39.2)$ & $73(60.8)$ & & $28(45.2)$ & $34(54.8)$ & & $14(29.2)$ & $34(70.8)$ & \\
\hline
\end{tabular}

Significant P-values are given in bold. AC, adenocarcinoma; SQC, squamous cell carcinoma.
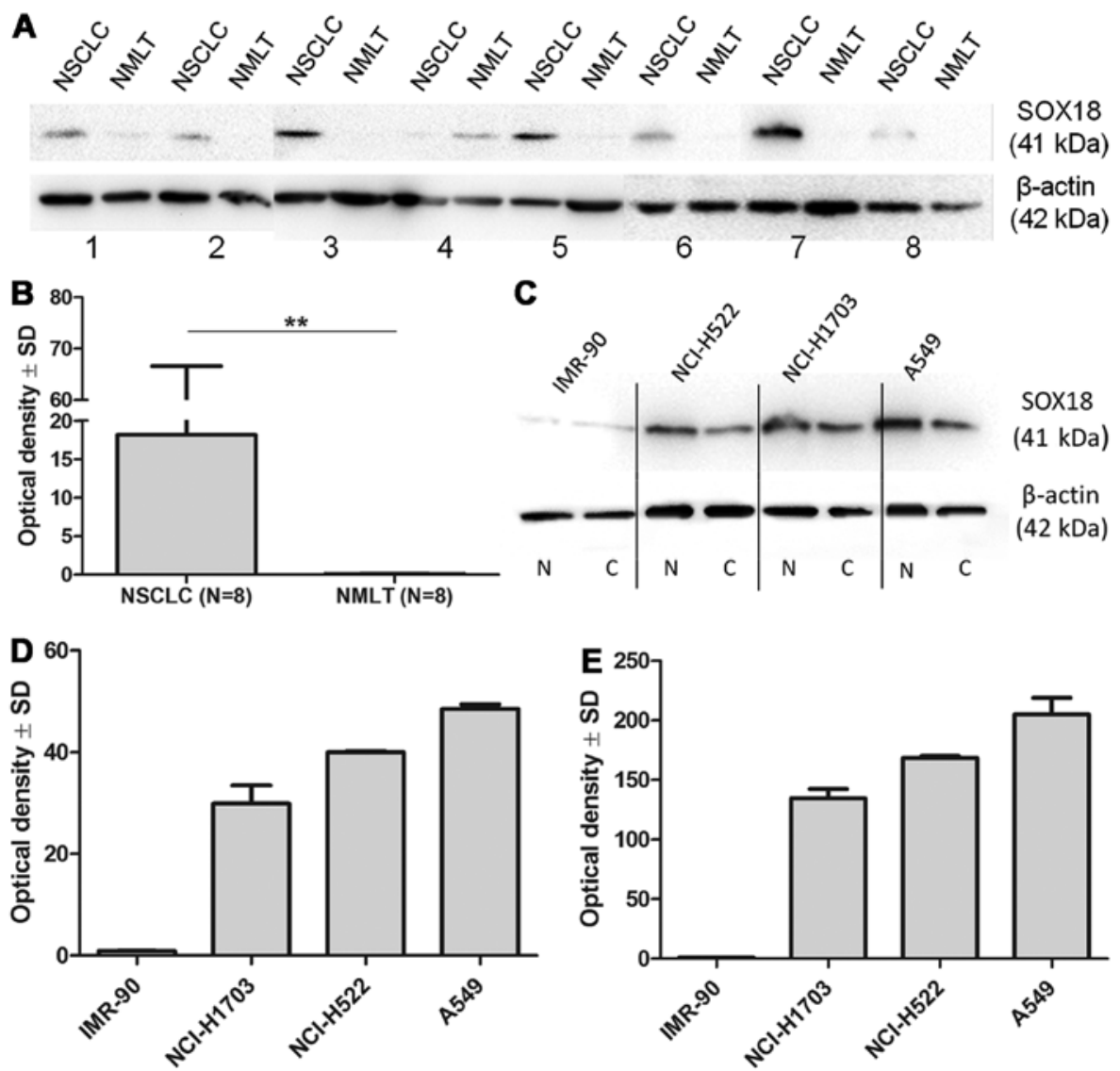

Figure 5. SOX18 protein expression in samples of non-small cell lung cancer (NSCLC) and non-malignant lung tissue (NMLT). Pairs are indicated by numbers below the $\beta$-actin bands (A). Densitometric measurement of the bands revealed a significantly higher SOX18 protein expression in NSCLC than in NMLT ("P<0.05, Wilcoxon-signed rank test). SOX18 levels were normalized against $\beta$-actin and one of the NMLT samples was assigned as a calibrator sample (B). Nuclear (N) as well as cytoplasm/membrane (C) fractions of all the examined lung-cancer cell lines (NCI-H1703, NCI-H522 and A549) and lung fibroblasts (IMR-90) (C). Densitometric analysis of the bands revealed virtually no expression of SOX18 protein in either the nuclear (D) or the cytoplasmic/membrane fraction (E) of the IMR-90 cell line. Strong SOX18 expression was noted in both cellular compartments in the analysed NSCLC cancer cell lines. SOX18 levels were normalized against $\beta$-actin and IMR-90 was assigned as a calibrator sample. 
Table III. Association of cytoplasmic SOX18 (cSOX18) expression with clinical and pathological data of the studied patients.

\begin{tabular}{|c|c|c|c|c|c|c|c|c|c|}
\hline \multirow[b]{2}{*}{ Parameters } & \multicolumn{2}{|c|}{ All cases $(\mathrm{N}=198)$} & \multirow[b]{2}{*}{ P-value } & \multicolumn{2}{|c|}{$\mathrm{AC}(\mathrm{N}=94)$} & \multirow[b]{2}{*}{ P-value } & \multicolumn{2}{|c|}{ SQC (N=89) } & \multirow[b]{2}{*}{ P-value } \\
\hline & $\begin{array}{c}\text { IRS } 0 \\
\mathrm{n}(\%)\end{array}$ & $\begin{array}{c}\text { IRS } 1-12 \\
\text { n }(\%)\end{array}$ & & $\begin{array}{l}\text { IRS } 0 \\
\mathrm{n}(\%)\end{array}$ & $\begin{array}{c}\text { IRS } 1-12 \\
\text { n }(\%)\end{array}$ & & $\begin{array}{l}\text { IRS } 0 \\
\text { n }(\%)\end{array}$ & $\begin{array}{c}\text { IRS } 1-12 \\
\text { n (\%) }\end{array}$ & \\
\hline \multicolumn{10}{|l|}{ Age (years) } \\
\hline$<65$ & $60(52.2)$ & $55(47.8)$ & 0.8853 & $33(56.9)$ & $25(43.1)$ & 0.5311 & $22(47.8)$ & $24(52.2)$ & 0.3974 \\
\hline$\geq 65$ & $45(54.2)$ & $38(45.8)$ & & $18(50)$ & $18(50)$ & & $25(58.1)$ & $18(41.9)$ & \\
\hline \multicolumn{10}{|l|}{ Gender } \\
\hline Male & $70(47)$ & $79(53)$ & 0.5116 & $39(55.7)$ & $31(44.3)$ & 0.6434 & $35(50.7)$ & $34(49.3)$ & 0.6120 \\
\hline Female & $26(53.1)$ & $23(46.9)$ & & $12(50)$ & $12(50)$ & & $12(60)$ & $8(40)$ & \\
\hline \multicolumn{10}{|l|}{ Tumour size } \\
\hline pT1 & $33(56.9)$ & $25(43.1)$ & 0.5331 & $17(63)$ & $10(27)$ & 0.3616 & $13(50)$ & $13(50)$ & 0.8170 \\
\hline pT2-pT4 & $72(51.4)$ & $68(48.6)$ & & $34(50.7)$ & $33(49.3)$ & & $34(54)$ & $29(46)$ & \\
\hline \multicolumn{10}{|c|}{ Lymph nodes } \\
\hline pNO & $59(55.1)$ & $48(44.9)$ & 0.5687 & $25(58.1)$ & $18(41.9)$ & 0.6765 & $28(53.8)$ & $24(46.2)$ & 0.8328 \\
\hline $\mathrm{pN} 1, \mathrm{pN} 2$ & $46(50.5)$ & $45(49.5)$ & & $26(52)$ & $24(48)$ & & $19(51.4)$ & $18(48.6)$ & \\
\hline \multicolumn{10}{|l|}{ Stage } \\
\hline I & $45(55.6)$ & $36(44.4)$ & 0.5660 & $18(56.3)$ & $14(43.7)$ & 0.8295 & $22(53.7)$ & $19(46.3)$ & 1.0000 \\
\hline II-IV & $60(51.3)$ & $57(48.7)$ & & $33(53.2)$ & $29(46.8)$ & & $25(52.1)$ & $23(47.9)$ & \\
\hline
\end{tabular}

IRS, immunoreactive score; AC, adenocarcinoma; SQC, squamous cell carcinoma.

Table IV. SOX18 mRNA expression, and clinical and pathological data of non-small cell lung cancer patients.

\begin{tabular}{|c|c|c|c|}
\hline Parameters & $\begin{array}{l}\text { Analysed cases } \\
\text { n }(\%)\end{array}$ & $\mathrm{RQ} \pm \mathrm{SD}$ & $\mathrm{P}$-value \\
\hline \multicolumn{4}{|l|}{ Age (years) } \\
\hline$<65$ & $26(61.9)$ & $0.5585 \pm 1.158$ & 0.4762 \\
\hline$\geq 65$ & $16(38.1)$ & $0.3937 \pm 0.3521$ & \\
\hline \multicolumn{4}{|l|}{ Gender } \\
\hline Male & $32(76.2)$ & $0.5353 \pm 1.053$ & 0.7341 \\
\hline Female & $10(23.8)$ & $0.3688 \pm 0.3461$ & \\
\hline \multicolumn{4}{|c|}{ Malignancy grade } \\
\hline $\mathrm{G} 2$ & $27(64.3)$ & $0.5023 \pm 0.9666$ & 0.5286 \\
\hline $\mathrm{G} 3, \mathrm{LCC}$ & $15(35.7)$ & $0.4837 \pm 0.9010$ & \\
\hline \multicolumn{4}{|l|}{ Tumour size } \\
\hline pT1 & $15(35.7)$ & $0.7107 \pm 1.264$ & 0.0929 \\
\hline pT2-pT4 & $27(64.3)$ & $0.3762 \pm 0.6857$ & \\
\hline \multicolumn{4}{|c|}{ Lymph nodes } \\
\hline pNO & $25(59.5)$ & $0.6411 \pm 1.181$ & 0.7390 \\
\hline $\mathrm{pN} 1, \mathrm{pN} 2$ & $17(40.5)$ & $0.2818 \pm 0.2377$ & \\
\hline \multicolumn{4}{|l|}{ Stage } \\
\hline I & $18(42.9)$ & $0.6160 \pm 1.175$ & 0.5005 \\
\hline II-IV & $24(57.1)$ & $0.4055 \pm 0.7145$ & \\
\hline
\end{tabular}

RQ, relative expression; SD, standard deviation; LCC, large cell carcinoma.
mRNA expression level and patients' clinical and pathological data (Table IV).

SOX18 expression determined in the paired frozen samples of NMLT and NSCLC using the western blot technique revealed significantly higher expression in the latter $(18.18 \pm 48.44$ vs. $0.05 \pm 0.06, P=0.018$, Wilcoxon signed-rank test; Fig. $5 \mathrm{~A}$ and $\mathrm{B})$.

SOX18 expression in lung cancer cell lines and normal lung fibroblasts. Analysis of SOX18 protein levels using the western blot technique in the studied cell lines revealed increased expression in the cytoplasmic/membranous fraction, as well as in the nuclear fraction, of NCI-H1703, NCI-H522 and A549 cancer cell lines (Fig. 5C-E). However, no SOX18 expression could be noted in the corresponding cellular fractions of the normal lung fibroblast cell line (IMR-90).

Prognostic significance of SOX18 expression in NSCLC. Univariate analysis of patient survival in the whole study group revealed that the presence of cytoplasmic SOX18 expression was associated with poor patient outcome $(\mathrm{P}=0.0077$; Table V). From among the factors considered in this group, $\mathrm{AC}$ histological type $(\mathrm{P}=0.0076)$, larger primary tumour size $(\mathrm{P}=0.0056)$, presence of lymph node metastases $(\mathrm{P}=0.0001)$, advanced disease stage $(\mathrm{P}=0.0004)$ and patient age $(\mathrm{P}=0.0085)$ were also associated with poor prognosis. Cytoplasmic SOX18 expression was a negative prognostic factor also in the group of $94 \mathrm{AC}(\mathrm{P}=0.0048)$, as were larger primary tumour size $(\mathrm{P}=0.0197)$, the presence of lymph node metastases $(\mathrm{P}=0.0064)$, advanced disease stage $(\mathrm{P}=0.0291)$ 
Table V. Univariate survival analysis of the whole study cohort and in the adenocarcinoma and squamous cell lung cancer patients.

\begin{tabular}{|c|c|c|c|}
\hline \multirow[b]{2}{*}{ Parameters } & \multicolumn{3}{|c|}{ Overall survival } \\
\hline & HR & $95 \% \mathrm{CI}$ & P-value \\
\hline \multicolumn{4}{|l|}{ All patients } \\
\hline nSOX18 ( $\leq 25$ vs. $>25 \%)$ & 1.012 & $0.6765-1.513$ & 0.9546 \\
\hline cSOX18 (IRS 0 vs. $1-12$ ) & 1.748 & $1.159-2.635$ & 0.0077 \\
\hline Ki-67 antigen ( $\leq 25$ vs. $>25 \%)$ & 1.017 & $0.6812-1.519$ & 0.9333 \\
\hline Histological type (AC vs. SQC vs. LCC) & - & - & 0.0297 \\
\hline Histological type (AC vs. SQC and LCC) & 1.728 & $1.156-2.582$ & 0.0076 \\
\hline Malignancy grade (G1, G2 vs. G3, LCC) & 1.553 & $0.9707-2.483$ & 0.0664 \\
\hline Tumour size (pT1 vs. pT2-pT4) & 1.837 & $1.195-2.825$ & 0.0056 \\
\hline Lymph nodes (pN0 vs. pN1, pN2) & 2.741 & $1.838-4.086$ & 0.0001 \\
\hline Stage (I vs. II-IV) & 2.059 & $1.379-3.075$ & 0.0004 \\
\hline Gender (male vs. female) & 1.235 & $0.7802-1.956$ & 0.3673 \\
\hline Age $(\leq 65$ vs. $>65$ years $)$ & 1.759 & $1.057-3.440$ & 0.0085 \\
\hline \multicolumn{4}{|l|}{ Adenocarcinoma (AC) } \\
\hline nSOX18 ( $\leq 25$ vs. $>25 \%)$ & 0.9724 & $0.5634-1.678$ & 0.9200 \\
\hline cSOX18 (IRS 0 vs. 1-12) & 2.267 & $1.284-4.004$ & 0.0048 \\
\hline Ki-67 antigen ( $\leq 25$ vs. $>25 \%)$ & 1.276 & $0.7464-2.180$ & 0.3732 \\
\hline Malignancy grade (G1, G2 vs. G3) & 1.618 & $0.8065-3.247$ & 0.1755 \\
\hline Tumour size (pT1 vs. pT2-pT4) & 2.017 & $1.119-3.638$ & 0.0197 \\
\hline Lymph nodes (pN0 vs. pN1, pN2) & 2.137 & $1.238-3.687$ & 0.0064 \\
\hline Stage (I vs. II-IV) & 1.861 & $1.065-3.251$ & 0.0291 \\
\hline Gender (male vs. female) & 0.9261 & $0.4964-1.728$ & 0.8093 \\
\hline Age $(\leq 65$ vs. $>65$ years $)$ & 1.906 & $1.057-3.440$ & 0.0321 \\
\hline \multicolumn{4}{|l|}{ Squamous cell carcinoma (SQC) } \\
\hline nSOX18 ( $\leq 25$ vs. $>25 \%)$ & 1.172 & $0.5941-2.311$ & 0.6476 \\
\hline cSOX18 (IRS 0 vs. 1-12) & 1.395 & $0.7165-2.718$ & 0.3272 \\
\hline Ki-67 antigen ( $\leq 25$ vs. $>25 \%)$ & 0.8592 & $0.4349-1.697$ & 0.6623 \\
\hline Malignancy grade (G1, G2 vs. G3) & 2.548 & $1.027-6.318$ & 0.0436 \\
\hline Tumour size (pT1 vs. pT2-pT4) & 1.262 & $0.6063-2.627$ & 0.5337 \\
\hline Lymph nodes (pN0 vs. pN1, pN2) & 3.262 & $1.656-6.426$ & 0.0006 \\
\hline Stage (I vs. II-IV) & 1.864 & $0.9567-3.631$ & 0.0673 \\
\hline Gender (male vs. female) & 1.774 & $0.8198-3.838$ & 0.1456 \\
\hline Age $(\leq 65$ vs. $>65$ years $)$ & 1.609 & $0.8249-3.139$ & 0.1629 \\
\hline
\end{tabular}

Significant P-values are given in bold. HR, hazard ratio; CI, confidence interval; nSOX18, nuclear SOX18; cSOX18, cytoplasmic SOX18; AC, adenocarcinoma; SQC, squamous cell carcinoma; LCC, large cell carcinoma.

and age $(\mathrm{P}=0.321)$ (Table $\mathrm{V})$. Univariate survival analysis in the SQC group showed that $\mathrm{G} 3$ malignancy grade $(\mathrm{P}=0.0436)$ and the presence of lymph node metastases $(\mathrm{P}=0.0006)$ were associated with poor patient survival (Table V).

\section{Discussion}

Accumulating lines of evidence point to the potential role of SOX18 transcription factor in the progression of various cancers. Recently, we showed that high nuclear immunoreactivity in cancer cells of IDC is associated with higher malignancy grade and HER2 amplification (19). SOX18 expression has also been detected in cell lines derived from melanoma, as well as from gastric, pancreatic and breast cancer $(16,18,19)$. Moreover, increased SOX18 expression in gastric cancer stroma (though not in cancer cells) was associated with poor outcome of the patients (20). SOX18 expression has also been studied in NSCLC tissues and its derived cancer cell lines, but only on the mRNA level (and without addressing its prognostic value) $(22,23)$.

To the best of our knowledge, we are the first to assess SOX18 expression on the protein level (using both IHC and the western blot technique) in NMLT, NSCLC specimens and cancer cell lines. We observed SOX18 immunoreactivity in the nuclei and cytoplasm of cancer cells in paraffin sections, as well as in the lung cancer cell lines that we 
investigated (NCI-H1703, NCI-H522 and A549). The results of the present study are in line with our previous observations regarding SOX18 expression in IDC tissues and its cell lines (19). Moreover, in the current study, as well as in that of Pula et al (19), we detected no SOX18 expression in fibroblasts of immunostained paraffin sections of NSCLC and IDC. In addition, no expression of this transcription factor was noted in the fibroblastic cell lines IMR-90 and NHDF which corresponds well with the results derived from the IHC sections. The cytoplasmic expression of SOX18 in lung cancer cells may be partly explained by the structure of this transcription factor. The HMG domain of this transcription factor has been shown to be capable of binding other compounds, thus mediating protein-protein interactions $(28,29)$. It may be possible that SOX18 has additional unrecognized functions in cytoplasm, such as regulating the activity of the Wnt signalling pathway, as has been demonstrated for the other members of the SOX F family, SOX7 and SOX17 $(30,31)$.

We observed a discrepancy between the mRNA and protein expression of SOX18 in NMLT and NSCLC tissues. We noted significantly lower mRNA expression levels of this transcription factor in the paired tissues and in all of the studied NSCLC tissues, as compared to NMLT. This finding is in accordance with the previous observations of Azhikina et al (23) and Dammann et al (22), who identified higher methylation levels of SOX18 promoter in NSCLC tissues and lung cancer cell lines. In contrast to SOX18 mRNA levels, its protein expression increased in NSCLC tissues, as determined utilizing the western blot technique. Due to these discrepancies, our findings may point to the existence of a negative regulative feedback loop in SOX18 expression. Based on the previous observations of Azhikina et al (23) and Dammann et al (22), it is possible that the decreased SOX 18 mRNA expression in NSCLC tissues is caused by promoter hypermethylation, which is frequently observed in this malignancy (32). Transcription factors of the SOX F group have been shown to complement their functions during angiogenesis and lymphangiogenesis $(8,10,11)$. In line with the above mentioned capability, SOX7 and $S O X 17 \mathrm{mRNA}$ expression have also been shown to be significantly downregulated in NSCLC as compared to NMLT $(31,33,34)$.

In this study, we observed a positive correlation between nuclear SOX18 immunoreactivity and that of the Ki-67 antigen in cancer cells of NSCLC. These observations may point to a possible role of SOX18 in the regulation of the proliferation rate of cancer cells. Previous studies have shown that SOX18 expression influences the proliferation of MCF-7 and VSMC cell lines $(16,21)$. Inhibition of this protein leads to a decrease in the proliferation of both cell lines. Moreover, the impact of SOX18 on cellular proliferation may be indirectly supported by the results of Darby et al (15), who showed that SOX18 mRNA expression increased during wound healing and diminished after the process ended.

In the present study, we have demonstrated that cytoplasmic SOX18 expression is associated with poor patient outcome for both the study cohort as a whole and for the AC subtype only. Interestingly, the intensity of immunoreactivity of SOX18 nuclei did not influence patient survival, although a positive correlation with the expression of Ki-67 antigen was recorded. The latter also increased with the malignancy grade of the tumours, but did not impact patients' overall survival.
The observed poor outcome of NSCLC and AC patients characterized by increased cytoplasmic SOX18 expression may result from its possible regulation of the Wnt signalling pathway (30). Nevertheless, further studies are needed to fully clarify this mechanism.

In summary, we have shown for the first time that SOX18 is expressed in cancer cells and vessels of NSCLC. Moreover, its expression is differentiated in regard to cellular localization. Based on our observations, cytoplasmic expression of SOX18 may be a new prognostic marker of poor prognosis in NSCLC. However, further studies are needed to warrant its prognostic utility in this malignancy.

\section{Acknowledgements}

The present study was supported by a research grant from the Wrovasc Integrated Cardiovascular Centre Project, and co-financed by the European Regional Development Fund within the Innovative Economy Operational Program, 20072013 realized in Regional Specialist Hospital, Research and Development Centre in Wroclaw.

\section{References}

1. Siegel R, Naishadham D and Jemal A: Cancer statistics, 2013. CA Cancer J Clin 63: 11-30, 2013.

2. Brandao GD, Brega EF and Spatz A: The role of molecular pathology in non-small-cell lung carcinoma-now and in the future. Curr Oncol 19 (Suppl 1): S24-S32, 2012.

3. Wegner M: From head to toes: the multiple facets of Sox proteins. Nucleic Acids Res 27: 1409-1420, 1999.

4. Harley VR, Lovell-Badge R and Goodfellow PN: Definition of a consensus DNA binding site for SRY. Nucleic Acids Res 22: 1500-1501, 1994

5. Wegner M: All-purpose Sox: the many roles of Sox proteins in gene expression. Int J Biochem Cell Biol 42: 381-390, 2010.

6. Francois M, Koopman P and Beltrame M: SoxF genes: key players in the development of the cardio-vascular system. Int J Biochem Cell Biol 42: 445-448, 2010.

7. Cermenati S, Moleri S, Cimbro S, et al: Sox 18 and Sox7 play redundant roles in vascular development. Blood 111: 2657-2666, 2008.

8. Hosking B, Francois M, Wilhelm D, et al: Sox7 and Sox17 are strain-specific modifiers of the lymphangiogenic defects caused by Sox18 dysfunction in mice. Development 136: 2385-2391, 2009.

9. Matsui T, Kanai-Azuma M, Hara K, et al: Redundant roles of Sox 17 and Sox 18 in postnatal angiogenesis in mice. J Cell Sci 119: 3513-3526, 2006.

10. Sakamoto Y, Hara K, Kanai-Azuma M, et al: Redundant roles of Sox 17 and Sox 18 in early cardiovascular development of mouse embryos. Biochem Biophys Res Commun 360: 539-544, 2007.

11. Herpers R, van de Kamp E, Duckers HJ and Schulte-Merker S: Redundant roles for sox7 and sox18 in arteriovenous specification in zebrafish. Circ Res 102: 12-15, 2008.

12. Downes M, Francois M, Ferguson C, et al: Vascular defects in a mouse model of hypotrichosis-lymphedema-telangiectasia syndrome indicate a role for SOX18 in blood vessel maturation. Hum Mol Genet 18: 2839-2850, 2009.

13. Francois M, Caprini A, Hosking B, et al: Sox18 induces development of the lymphatic vasculature in mice. Nature 456: 643-647, 2008.

14. Irrthum A, Devriendt K, Chitayat D, et al: Mutations in the transcription factor gene SOX18 underlie recessive and dominant forms of hypotrichosis-lymphedema-telangiectasia. Am J Hum Genet 72: 1470-1478, 2003.

15. Darby IA, Bisucci T, Raghoenath S, et al: Sox 18 is transiently expressed during angiogenesis in granulation tissue of skin wounds with an identical expression pattern to Flk-1 mRNA. Lab Invest 81: 937-943, 2001. 
16. Young N, Hahn CN, Poh A, et al: Effect of disrupted SOX18 transcription factor function on tumor growth, vascularization, and endothelial development. J Natl Cancer Inst 98: 1060-1067, 2006.

17. Duong T, Proulx ST, Luciani P, et al: Genetic ablation of SOX18 function suppresses tumor lymphangiogenesis and metastasis of melanoma in mice. Cancer Res 72: 3105-3114, 2012.

18. Saitoh T and Katoh M: Expression of human SOX18 in normal tissues and tumors. Int J Mol Med 10: 339-344, 2002.

19. Pula B, Olbromski M, Wojnar A, et al: Impact of SOX18 expression in cancer cells and vessels on the outcome of invasive ductal breast carcinoma. Cell Oncol (Dordr) 36: 469-483, 2013.

20. Eom BW, Jo MJ, Kook MC, et al: The lymphangiogenic factor SOX 18: a key indicator to stage gastric tumor progression. Int J Cancer 131: 41-48, 2012.

21. Garcia-Ramirez M, Martinez-Gonzalez J, Juan-Babot JO, et al: Transcription factor SOX18 is expressed in human coronary atherosclerotic lesions and regulates DNA synthesis and vascular cell growth. Arterioscler Thromb Vasc Biol 25: 2398-2403, 2005.

22. Dammann R, Strunnikova M, Schagdarsurengin U, et al: CpG island methylation and expression of tumour-associated genes in lung carcinoma. Eur J Cancer 41: 1223-1236, 2005.

23. Azhikina T, Kozlova A, Skvortsov T and Sverdlov E Heterogeneity and degree of TIMP4, GATA4, SOX18, and EGFL7 gene promoter methylation in non-small cell lung cancer and surrounding tissues. Cancer Genet 204: 492-500, 2011.

24. Detterbeck FC, Boffa DJ and Tanoue LT: The new lung cancer staging system. Chest 136: 260-271, 2009.

25. Remmele W and Stegner HE: Recommendation for uniform definition of an immunoreactive score (IRS) for immunohistochemical estrogen receptor detection (ER-ICA) in breast cancer tissue. Pathologe 8: 138-140, 1987 (In German).
26. Werynska B, Pula B, Muszczynska-Bernhard B, et al: Metallothionein $1 \mathrm{~F}$ and $2 \mathrm{~A}$ overexpression predicts poor outcome of non-small cell lung cancer patients. Exp Mol Pathol 94: 301-308, 2013.

27. Doroudi R, Andersson M, Svensson PA, et al: Methodological studies of multiple reference genes as endogenous controls in vascular gene expression studies. Endothelium 12: 215-223, 2005.

28. Lefebvre V, Dumitriu B, Penzo-Mendez A, et al: Control of cell fate and differentiation by Sry-related high-mobility-group box (Sox) transcription factors. Int J Biochem Cell Biol 39: 2195-2214, 2007.

29. Wilson M and Koopman P: Matching SOX: partner proteins and co-factors of the SOX family of transcriptional regulators. Curr Opin Genet Dev 12: 441-446, 2002.

30. Zhu Y, Li Y, Jun Wei JW and Liu X: The role of sox genes in lung morphogenesis and cancer. Int J Mol Sci 13: 15767-15783, 2012.

31. Yin D, Jia Y, Yu Y, et al: SOX17 methylation inhibits its antagonism of Wnt signaling pathway in lung cancer. Discov Med 14: 33-40, 2012.

32. Tessema M, Willink R, Do K, et al: Promoter methylation of genes in and around the candidate lung cancer susceptibility locus 6q23-25. Cancer Res 68: 1707-1714, 2008.

33. Hayano T, Garg M, Yin D, et al: SOX7 is down-regulated in lung cancer. J Exp Clin Cancer Res 32: 17, 2013.

34. Li B, Ge Z, Song S, et al: Decreased expression of SOX7 is correlated with poor prognosis in lung adenocarcinoma patients. Pathol Oncol Res 18: 1039-1045, 2012. 